\title{
Emergence of mobilization challenger in the field: An anti-redevelopment movement of Rumah Susun Klender in East Jakarta
}

\author{
Galang Anugrah ${ }^{1^{*}}$ \\ ${ }^{1}$ Department of Sociology, Universitas Indonesia, Indonesia \\ "Corresponding author \\ E-mail address: galanganugrah52@gmail.com \\ DOI: https://doi.org/10.21107/sml.v4i1.9852
}

\begin{tabular}{|c|c|}
\hline Article Info & ABStRACT \\
\hline $\begin{array}{l}\text { Keywords: } \\
\text { emergent } \\
\text { mobilization } \\
\text { challengers } \\
\text { field theory } \\
\text { public housing } \\
\text { redevelopment } \\
\text { Indonesia }\end{array}$ & $\begin{array}{l}\text { This article aims to analyze the emergence of challengers of mobilization } \\
\text { in the case of a movement against the redevelopment plan of Rumah } \\
\text { Susun Klender in East Jakarta using a field theory approach. Mobilization } \\
\text { issues around housing in Indonesia are not new, but it is still dominated } \\
\text { by evictions issues. Therefore, the Rumah Susun Klender case can be } \\
\text { considered unique. Using the case study method, data were obtained } \\
\text { through several observation techniques, such as document study and in- } \\
\text { depth interviews with } 10 \text { informants. The results of the analysis reveal that } \\
\text { the transformation of people resistance into the emergence of Paguyuban } \\
\text { Tandingan (rival organization) as challenger of mobilization is not merely } \\
\text { caused by redevelopment plans. Indeed, it was generated by an initial } \\
\text { contention (internal dynamics) that occurred between the residents and the } \\
\text { Association of Apartment Owners and Occupants (P3SRS). The residents } \\
\text { who are anti-redevelopment was consolidated by, and joined with, the rival } \\
\text { organization to take over P3SRS' authority as a governance unit to achieve } \\
\text { one goal: cancelling the redevelopment plan. }\end{array}$ \\
\hline
\end{tabular}

Citation suggestion:

Anugrah, G. (2021). Emergent mobilization of challenger in the field: An anti-redevelopment movement of Rumah Susun Klender in East Jakarta. Simulacra, 4(1), 29-42. https://doi.org/10.21107/sml.v4i1.9852

Received 6 February 2021; Received in revised form 16 April 2021; Accepted 28 April 2021; Published online 25 June 2021. 


\section{Introduction}

For decades, public housing has become a significant concern in the global south (Forrest, 2014). Public housing is a form of social policy to fulfill citizens' rights regarding access to housing (Chiodelli, 2016). In the Indonesian context, public housing development policies can be traced from Soekarno's regime (Colombijn, 2011; Kusno, 2012). One of the most common type of public housing in modern Indonesia is vertical housing, locally known rumah susun (flats). The development of flats is often seen as an alternative way to provide public housing for those classified as middle and lower socio-economic classes who live in densely populated urban areas (Vialita \& Rahmawati, 2020; Warouw et al., 2010). Flats can be said as a product of inequality and rapid urbanization.

In 2018, Jakarta had a total 61 flats (BPS, 2018). However, the trajectory of vertical housing cannot be separated from contentions. Recently, there is an ongoing conflict in Rumah Susun Klender, East Jakarta. The conflict was triggered by the redevelopment plan from the State Housing Provider Agency (PERUMNAS). The development plan was initiated by the Association of Apartment Owners and Occupants (P3SRS) in Klender. Unfortunately, the plan has caused horizontal conflict among residents, and as a consequence, divided them into two groups: the pro-redevelopment group and antiredevelopment group. The anti-development group then consolidated into a Paguyuban Tandingan group (rival organization) which was established during the contention. The rival organization mobilized the antiredevelopment movement from mid2018 to resist the implementation of the redevelopment plan (Hidayat, 2019).

Resistance around public housing is not a new phenomenon in Indonesia. These conflicts tend to be dominated by evictions and vertical clashes between civil society visà-vis the state or developers (Andri A, 2011; Sutanudjaja et al., 2019; Syafruddin \& Adi, 2017); However, the redevelopment plan conflict in Rumah Susun Klender is different from the common cases. For example, public housing redevelopment issues outside Indonesia, such as Australia, where, despite the redevelopment receiving pro and cons from residents who were the target of the program, the redevelopment did not trigger an organized protest movement from resistance groups (Hoatson \& Grace, 2002; Wynne \& Rogers, 2020).

These days, the construction of vertical housing in Indonesia is still prone to issues, such as the land market (availability and price of land) (Komalawati \& Lim, 2020), as well as poor management of flats which often results in horizontal conflicts between residents and P3SRS (Widhana, 2017). Issues related to poor management often include lack of financial transparency and corruption (Hidayat \& Sumandoyo, 2017). From the analysis of the previous literature, it can be concluded that the resistance movement in Rumah Susun Klender is a unique case in the public housing issue landscape in Indonesia because it is an original, never before case.

The emergence of a conflict is often caused by different understanding and interests between two or more interacting groups (Kriesberg \& Dayton, 2012). The difference in interests is seen as a precondition for the formation of collective action that manifests in the protest movement (Meyer, 2012). However, resistance movements are not merely caused by differences in interests, but also shaped by the socio-cultural factors (Fringka, 2017; Hadi, 2018). Discussions of the phenomenon of conflict, especially in development issues, must go beyond the purpose of measuring how one aspect is more dominant than another. Indeed, it is crucial to understand the relationship between structures, culture, and social processes in 
society (Rachmawan, 2016; Wirutomo, 2012). Hence, the mobilization of resistance groups against the redevelopment plan of the Rumah Susun Klender cannot be simply reduced to the differences in people's understanding and interests; it requires analysis concerning the actors and their social relationship patterns.

Based on the case description, this study seeks to reveal the reasons behind the antiredevelopment stance of the residents and analyze the emergence of a redevelopment plan challenger group in Rumah Susun Klender case using a field theory approach. The field theory approach can explain social actors and their relationship patterns (including power relations) (Bourdieu, 2010; Martin, 2003). Fligstein and McAdam (2012) have recently introduced a further development of this theory, referred to as Strategic Action Fields (SAFs). It is the result of integrating various theories such as economic sociologists, institutional theorists in sociology and political science, as well as experts in social movements. The theory rests on a view that sees the field-defined as the meso-level social order-as the basic structural building blocks of modern political/organizational life in the economy, civil society, and the state (Fligstein \& McAdam, 2011, 2012).

The boundaries of the field are not fixed. It but depends on how the actors define the situations and issues at stake (Fligstein \& McAdam, 2012). Referring to Bourdieu, the field is synonymous with contestation in which there are groups of actors with dominant (incumbents) and less dominant (challengers) positions, and sometimes Internal Governance Units (Fligstein \& McAdam, 2012; Swartz, 2014). At the same time, Fligstein and McAdam (2012) also argue that with a deeper understanding of field dynamics, it can be understood as a condition in which exogenous shock and internal dynamics are sources of field destabilization, which to some extent has the potential to bring about changes.

Fligstein and McAdam (2012) considered the field to always favor the incumbent's interest as the dominant group. On the other hand, the challenger held a less privileged position and usually had little influence on the field. The challengers are always waiting for structural opportunities to open in the field to challenge the dominant actors (Domaradzka \& Wijkström, 2019; Fligstein \& McAdam, 2012). Thus, even though the field may seem stable, there will always be challengers watching and looking for the opportunity. Political sociologists call this opportunity as structural opportunities (Ancelovici, 2021; McAdam \& Boudet, 2012). When the opportunity arise, actors take advantage of the momentum to act strategically to mobilize resistance, not unlike the logic of opposition in social movement studies (Flacks, 2003; Snow et al., 2019), to fight against the dominant groups. Meanwhile, the governance unit is an organization or association whose task is to ensure that the system in the field functions as intended. This unit is an important resource in strengthening or maintaining a position (for both incumbent and challenger) in the field (Fligstein \& McAdam, 2012, p. 96). Governance unit has a role to enforce the rules and facilitate the smooth functioning of the system. It can serve one of five internal functions: administration, information, regulation, enforcement, certification. Efforts to control the unit are thus a form of strategic action to gain or maintain power in the field.

The mobility of actors in the field is determined by social skills (Fligstein, 2001), which is an actor's cognitive ability to read people and the environment, frame action lines, and mobilize other actors in the field. Actors use their skills to mobilize all available resources in the field, in Bourdieu's terms called the capital (Bourdieu, 2002), to build alliance for the sake of collective 
interests. The skilled actors in the incumbent group maintain their dominance, while the challenger group is against the status quo (Fligstein \& McAdam, 2011, 2012). Social skills are the main features that explain the micro-foundations of field theory. This study focuses on the interaction between actors in field, especially concerning the emergence of rival organization as challengers, including the examination of the social skills used by the actors in mobilizing their antiredevelopment movements in the case of Rumah Susun Klender.

\section{Method}

This research was conducted based on a qualitative method using a case study approach. The issues surrounding the redevelopment plan were conceptualized as a social field in which there are a group of incumbents, challengers, and governance units. Primary data were collected through direct observation techniques and in-depth interviews during the period November 2019-January 2020. The researchers interviewed 10 informants, which consists of five anti-redevelopment residents, and five

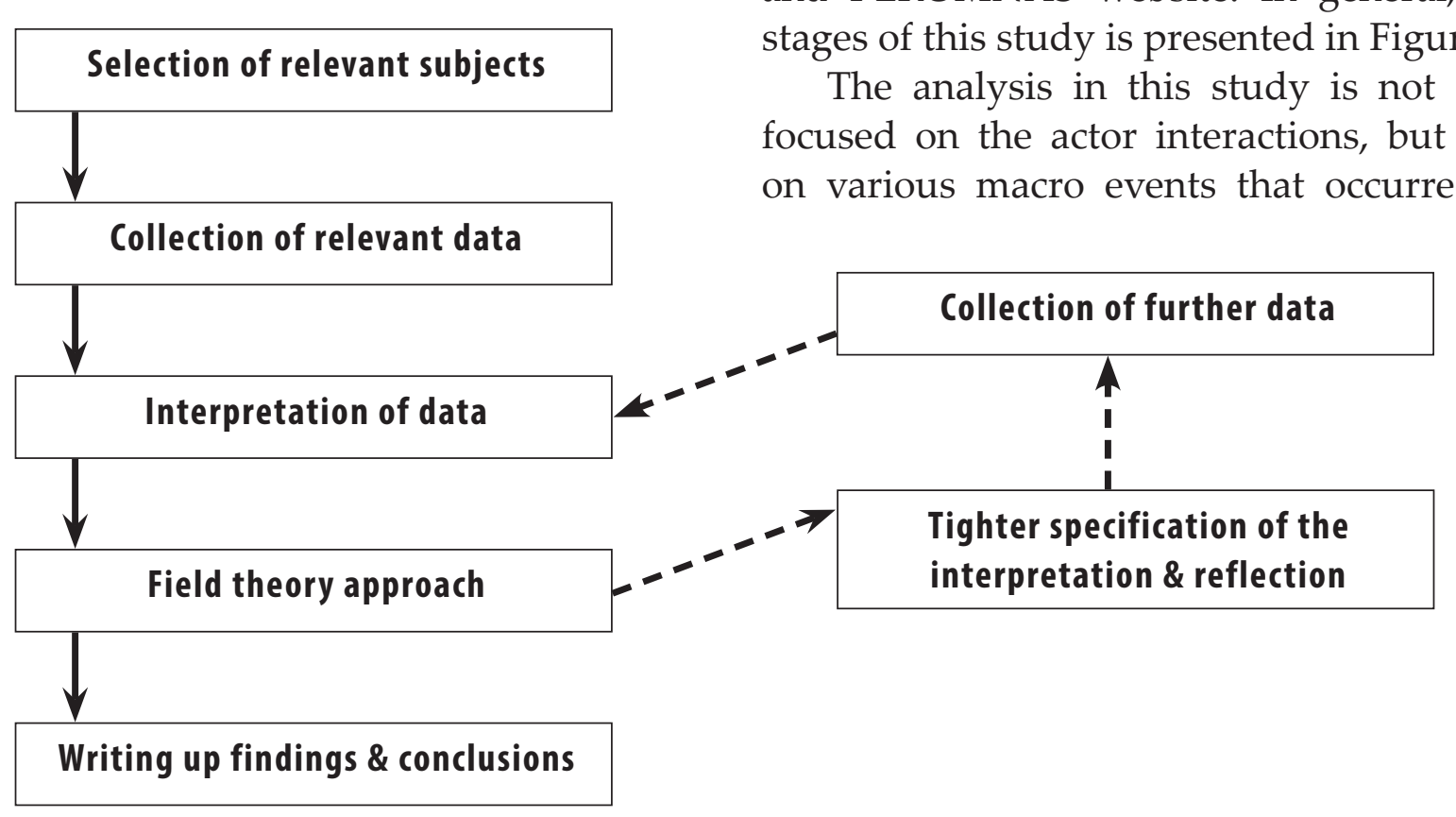

active members of the internal movement in the challenger group. This composition is based on the assumption that these informants are considered able to provide detailed information about the resistance in the context of Rumah Susun Klender. Meanwhile, due to the informant's request, their personal identities are kept confidential. To represent the informant's verbatim in this paper, only the initials are used.

Data were collected using a semistructured question model which aimed to gather information regarding the informants' views, knowledge, beliefs, motivations, reasons for the case being studied (Johnson \& Christensen, 2014). The researcher ensured that the informants' consent to be involved in the data collection process have been obtained before proceeding with the data collection. This process is necessary to maintain ethics and ensure the willingness of subjects to provide the required information (Bryman, 2012). To collect information at macro level, secondary data, researchers collected data from previous studies, archives, and local reports, national statistical yearbooks, online news related to Rumah Susun Klender, as well as the Jakarta Regional Government and PERUMNAS website. In general, the tages of this study is presented in Figure 1.

The analysis in this study is not only focused on the actor interactions, but also in 
the Rumah Susun Klender. Information was sorted from interview transcripts, field notes, documents, and visual materials such as photographs. Data quality was checked using triangulation techniques. Each informant was validated with data obtained from other informants during the field research (Creswell, 2014) assited by direct quotations from the interview transcripts and observation notes. This process is necessary to ensure consistent information, as well as the possibility of finding biases and inconsistencies between data (Berg \& Lune, 2012). The data validation was then carried out, to clarify any bias with reflexivity or interpretation from researchers. The use of this validation technique in field notes was aimed to explain the researchers' interpretation of the observed phenomena.

\section{Results and Discussion}

The explanation in this section is split into two sub-themes. Firstly, the description is focused on ruptures, or sources of shocks, which trigger the onset of contention among residents of the Rumah Susun Klender. Secondly, the discussion moves to reflects the emergence of rival organization and their strategic action to fight redevelopment plans in the field.

\section{Onset of contention: Redevelopment plan of Rumah Susun Klender}

Since 2017, the Indonesian state housing provider agency (PERUMNAS) has planned to redevelop the Rumah Susun Klender. The letter of the Governor of Capital City of Jakarta, Anies Baswedan, number 93/1.711.51 concerning principle permit states that the 100,151 m2 land in Klender will be redeveloped through the revitalization program (Tirto.id, 2019). The letter also stated that this program can be implemented because PERUMNAS data (see Table 1) indicates that up to 60 percent of residents have agreed with the plan. In accordance with Law no. 20 of 2011 concerning flats, especially in Article 65 paragraph (2), this is in line with regulations where the plan for redevelopment of flats must be approved by at least 60 percent of the members of the Association of Owners and Tenants of Condominium Unit (P3SRS) (Nusantara Pos, 2019).

Based on various data, there are at least two factors that may be the starting point for the emergence of anti-redevelopment groups: (1) discrepancies in perceptions and facts about program plans; (2) polemic of citizen consent data used as the basis for the plan. In the initial socialization process of the program by PERUMNAS and P3SRS, residents received information that the buildings of Rumah Susun Klender would be demolished and rebuilt into a 20-floors new building with. It should be noted that the Rumah Susun Klender currently consist of four floors. Standing on a land area of 11.3 hectares, the Rumah Susun Klender have 78 building blocks with a total of 1,280 units. This residential complex stretches lengthwise in two sub-districts (Kelurahan), namely Malaka Jaya and Malaka Sari, where there are 30 Neighborhood Unit (Rukun Tetangga - RT) and three Community Unit (Rukun Warga - RW). Based on historical aspects, flats in Klender have was built in the 1980s. The implementation of the construction itself began in July 1981 and was completed in December 1983, inaugurated by President Soeharto on September 3, 1985 (Marni, 2006).

After the redevelopment, it was planned that there would be various infrastructure, parks, and shopping centers designated as public facilities for residents. Later, the residents would be placed in units located on the 3rd floor and above as replacements for their old units. Meanwhile, the second and first floors were intended for commercial purposes. However, residents have different 
understandings about the concept. Some residents feel that the program is similar to the development of elite and luxury apartment areas instead of housing for middle and lower social-economy class, which worries them. Instead benefitting the residents, this plan is seen as a threat and a concern. The residents' doubts about the redevelopment plan were manifested in their worries about the shape of the building, the availability of facilities, and the cost of living after the redevelopment. One resident shared his concerns:

"We have collected information from many sources, but we could not find a luxury apartment like this (Klender). The apartment is not appropriate for us ..... because the fee would increase, higher than Rumah Susun Klender. You know that living in apartment is expensive. We disagree if this building will be demolished and rebuilt into a luxury apartment." (SP, interview, January 2020).

Meanwhile, facilities that residents currently use, such as subsidized gas and postpaid electricity, would be replaced with more modern ones. Currently, these facilities use a postpaid payment system where the money is deposited into P3SRS every month. The average monthly expenditure of residents for electricity, water, and gas is around 70-150 thousand rupiah, which is affordable for the residents. This adjustment to public facilities will affect the amount of management fees that must be paid each month Residents think these fees would increase two times from the current fee. This concern regarding the cost of living is quite reasonable, considering that most of the residents work in the informal sector and retired employees. Since luxury apartments are considered incongruence with residents who disagree with the redevelopment plan, then there is an assumption that the plan is actually as an way to evict the residents. Some of the residents even imagined that the new building is completely different than the current building. The new units are considered to be more luxurious and not suitable for middle class residents. This situation underlies the residents' worries of the program. The construction plan itself would dramatically alter the building. It was originally a four-floor building. After the redevelopment, it would become a 20 floors building. This situation may create a cultural shock among the original residents, which is becoming a great concern among the opposing side of the plan.

Most of the anti-redevelopment residents are from the first generation. It means that they have lived or were born in Klender in 1985 (RB, Interview January 2021). They have spent approximately 30 years of their lives in the Rumah Susun Klender. This duration is enough to create a social cohesion between residents and their living space. Between the two, there is an embeddedness that is socially constructed through involvements in various social group (such as youth organization, Indonesian family welfare movement, and other social gatherings), which then creates social bonds. Accordingly, the relationship between the residents and their place where they live cannot be reduced merely as an physical object. How social cohesion emerges was shown in a study conducted by Pasaribu (2013) in the residents of the Rumah Susun Tanah Abang in Central Jakarta. The residents of the flat define their living space as 'dwelling', which sociologically means a place where people live and interact with other residents and is characterized by their social involvement (Pasaribu, 2013). Housing issues are often reduced to a mere physical relation between the community and its living space, negating the emotional connection and cultural values that are created between the two (Wynne \& Rogers, 2020). Similarly, land compensation in cases of agrarian conflict is often reduced to mere economic relations without considering social and cultural values (Novenanto, 2015). 
The accumulation of experiences and interactions created between residents while living in a flat, in turn, constructs a sense of place that is embodied in their consciousness. The conception resulting from this long process creates closeness and socio-cultural ties between residents and their living spaces. In addition, residents' perceptions of the incompatibility of luxury apartments as a residential concept are the result of their reflection of their position in social reality. There is an assumption that luxury apartments are only suitable for people from the upper social class. On the other hand, this concern reveals a symptom of cultural shock that could affect the residents once the program is implemented.

The next problem is the data of residents' votes on the revitalization plan. The current data collected by the P3SRS shows that $60 \%$ of the residents support the plan (see

Table 1. Residents' votes on the revitalization of Rumah Susun Klender

\begin{tabular}{lcc}
\hline Votes & The Residents & (\%) \\
\hline Agree & 813 & $63.52 \%$ \\
Disagree & 36 & $2.81 \%$ \\
Abstain & 17 & $1.33 \%$ \\
Total data & 866 & $67.66 \%$ \\
Do not returning form yet & 414 & $32.34 \%$ \\
\hline Total & $\mathbf{1 2 8 0}$ & $\mathbf{1 0 0}$ \\
\hline
\end{tabular}

Source: Perumnas (2018).

Table 1). These votes have reached the minimum number required to carry out the revitalization agenda. As regulated in Law Number 20 Year 2011 concerning Flats, in Article 65 paragraph 2, to redevelop Rumah Susun Klender it requires at least $60 \%$ of P3SRS members' votes. Therefore, the PERUMNAS have the legal standing to carry out the plan. However, in fact, it was found that the data related to this agreement have caused conflicts and split the opinions of the residents of Rumah Susun Klender into two groups: pro-redevelopment and anti-redevelopment. The data presented is being questioned by those who are antiredevelopment. They believe that the method of vote collection is not democratic, participatory, or open. Furthermore, they argue that the data collection procedure was manipulative because it excludes a portion of the population in the sampling process. Arguably, the data did not fully represent the voices of Rumah Susun Klender residents because it only represents certain people. One resident believes that:

"It was said that residents who agree with the plans have reached 60 percent. The letter of approval (Principles Permit) was obtained by signing a letter from a community leader, signed by two village head (Lurah), three head of community unit (RW), and the Head of P3SRS. We don't know anything about the letter." (NS, Interview January 2020).

These accusations show that there is an implicit distrust among residents towards P3SRS. For many years, the relationship between the residents and the P3SRS has been incongruent which was indicated by the dissatisfaction of the residents with the performance of the P3SRS in Rumah Susun Klender (Nasution, 2004). Nasution (2004) found that most residents did not see the presence of this organization as the best standard for governing the flat. P3SRS is thought to have a generally lax approach to enforcing existing rules and regulations. For example, various informants of the study stated that public facilities, such as meeting halls and funeral houses, are rented by P3SRS to the public (non-residents) who are willing to pay, and not prioritizing the residents.

"The current management is not functional (dysfunction). There are too many allegations that they are corrupt. I heard that P3SRSK wants 
to control this (redevelopment plan). If they can influence everyone to agree, I heard that they will be given one billion rupiahs from PERUMNAS. That is why they manipulate the principle permits." (ED, Interview January 2020).

The commercialization practice is not followed by the accountability of funds to the public. Therefore, this situation further increases the residents' suspicion and sentiment to P3SRS. This case also adds to the list of problems in the trajectory of flat issues in Indonesia, most of which are caused by poor governance by P3SRS (Hidayat \& Sumandoyo, 2017; Widhana, 2017). In addition, the sense of distrust towards P3SRS becomes stronger when residents of the Rumah Susun Klender heard of the redevelopment plan initiated by P3SRS.

In sum, PERUMNAS's redevelopment project emerged as a crucial source of crisis. Fligstein and McAdam (2011, 2012) termed this situation as exogenous shock because it has destabilizing impact on the field. Indeed, this situation generated pros and cons among residents. Simultaneously, the redevelopment plan was used as an opportunity (Ancelovici, 2021; McAdam \& Boudet, 2012) by the anti-redevelopment group to expose their disappointment and transformed it into a resistance movement. Hence, the resistance was not entirely triggered by the exogenous shocks (redevelopment plan), but also influenced by the internal dynamics between actors (conflict among residents and the P3SRS). The combination of exogenous shock and internal dynamic, therefore, has become a fundamental source in causing ruptures in the field (Fligstein \& McAdam, 2011, 2012). In that sense, the redevelopment plan has become an onset of contention in the field along with the emergence of antiredevelopment mobilization.

\section{Rival organization: Emergent mobilization of challenger in the field}

In October 2018, a protest occurred in front of the P3SRS Klender office. This protest was a manifestation of the antiredevelopment movement against P3SRSK as the initiator of PERUMNAS' plan to redevelopment Rumah Susun Klender. Field identification of this issue is presented in figure 2). First and foremost, P3SRS is a legally recognized organization responsible for regulating and handling internal affairs in the Rumah Susun Klender. This organization has been mandated in various national and regional laws and regulations, including Law of the Republic of Indonesia Number 20

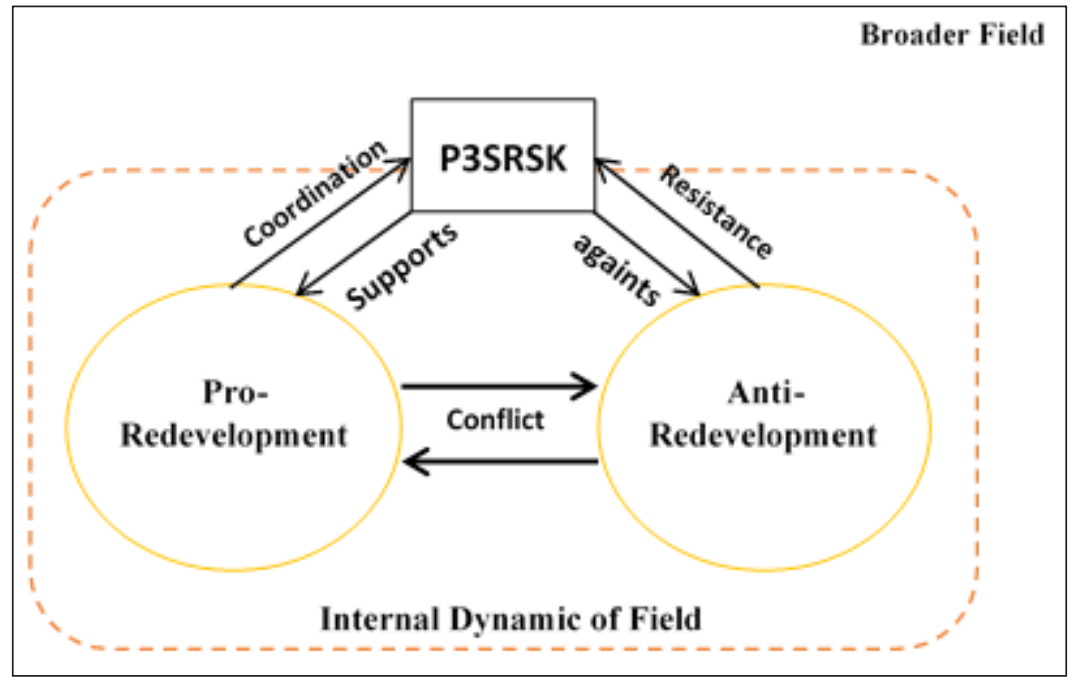

Figure 2. Interactions groups around field (Source: author's data) 
of 2011, Regulation of the Minister of Public Works and Public Housing no. 23 / PRT / M / 2018, and DKI Jakarta Regulation No. 5/2016. These regulations require P3SRS to compile, implement, and review working systems that cover all aspects of budget funds, resources, administration, and government accountability.

As previously explained, the relationship between P3SRS and residents of the Rumah Susun Klender is not entirely harmonious (Nasution, 2004). One reason for the disharmony is that the flat's public services have been commercialized by P3SRS which makes it seem that the residents' needs and rights are being neglected. P3SRS is deemed to be insensitive to community grievances. After the announcement of the Rumah Susun Klender redevelopment project, negative sentiment against P3SRS has become stronger. Residents opposed to redevelopment believed that P3SRS, whose main duty is to organize residents of the flats, wanted to use the initiative for financial profit.

"Initially the one who proposed the redevelopment plan was P3SRS.Then, they continued to coordinate with PERUMNAS. After that, PERUMNAS looked for developers for the program, but we still don't know who they have been chosen" (HS, Interview November 2020).

Accordingly, the anti-redevelopment residents believe that P3SRS has the authority to initiate or reject redevelopment plan. In this turmoil, a rival organization named Paguyuban Warga Rumah Susun Klender emerged as as rival organization to challenge P3SRS's authority in the field. This group was established in September 2018. Another function of the rival organization is to become a collective strategy for consolidating antiredevelopment residents in contesting P3SRSK's position with the ultimate goal to undo the redevelopment plan. A resident who is part of this organization believes that:
"Later, when we (the rival organization) succeed to acquire P3SRSK, our wishes can be negotiated. If we still do not have a leverage, if we want to have any concept or idea, even if it is brilliant, it will be hard to achieve. On the other hand, for the chairman of the association, if he has a concept, it can be implemented because he has an important position." (RB, Interview January 2020).

There is no fixed organizational structure of anti-redevelopment movement since it is organized based on collectivity and social networks among its members. It is not a formal, hierarchical, and structured organization. Structurally, there is only a leader and secretary, along with 10 members in internal group. This group was led by Rubinah, who was chosen by the members. She was chosen because she is seen as more experienced than other members because she had participated in the election for Regional Representative Council (Dewan Perwakilan Daerah-DPD) DKI Jakarta in 2009-2014. The experience and knowledge of their leader in previous political contestations became the basic social skills for the rival groups in mobilizing resistance in the field. Rubinah herself is also a respected and senior figure among the members. The rival organization, often referred as the Rubinah group, considers her as an influential figure in Rumah Susun Klender.

This resistant group's member meets weekly on Fridays to discuss strategies and the progress of their movement (see table 2). One goal that this group wants to achieve is to occupy a strategic position in P3SRS and to fight against the redevelopment plan. This group mobilizes anti-redevelopment residents to be consolidated into one to show the real data of residents' opinions on the plan. This action was done to match P3SRS data which became the PERUMNAS database. The anti-redevelopment data was collected by asking residents to sign a petition. This data would later be used by 
the rival organization as evidence that most of residents in the Rumah Susun Klender actually disagree with the redevelopment plan. After the data from the residents, especially those who anti-redevelopment, have been collected, it will be given to P3SRS and PERUMNAS.
In addition, the anti-redevelopment residents believed that the redevelopment project should not be implemented unless they had a right to build (Hak Guna Bangunan-HGB) that was recently extended until 2030. If the revitalization plan continues to be implemented, the residents demand

Table 2 Strategies and challenges in the field

\begin{tabular}{|c|c|}
\hline Strategies & Constraints \\
\hline $\begin{array}{l}\text { - Approaching and consolidating residents who } \\
\text { are anti-redevelopment plan }\end{array}$ & - There is no fixed organizational structure \\
\hline - Members meet weekly on Friday & - Attended by only a few people \\
\hline $\begin{array}{l}\text { - Collecting signatures or petition from anti- } \\
\text { redevelopment to challenge existing data from } \\
\text { P3SRSK }\end{array}$ & $\begin{array}{l}\text { - Limited data collection due to the lack of } \\
\text { human resources }\end{array}$ \\
\hline $\begin{array}{l}\text { - Installing banners and stickers as a form of } \\
\text { symbolic resistance }\end{array}$ & $\begin{array}{l}\text { - Does not have an significant effect in } \\
\text { gaining public attention }\end{array}$ \\
\hline $\begin{array}{l}\text { - Network expansion and support from outside } \\
\text { the community }\end{array}$ & $\begin{array}{l}\text { - Differences in interests that do not generate } \\
\text { consensus }\end{array}$ \\
\hline $\begin{array}{l}\text { - Sending the petition to the government (Mayor } \\
\text { of East Jakarta) }\end{array}$ & - The bureaucratic process is long and tiered \\
\hline $\begin{array}{l}\text { - Contest for positioning of chairman of the } \\
\text { P3SRSK }\end{array}$ & $\begin{array}{l}\text { - The rival organization has no legal basis } \\
\text { (non-formal) }\end{array}$ \\
\hline
\end{tabular}

Source: Author's primary data

The Indonesian Law no. 20 of 2011 concerning the implementation of redevelopment agenda becomes the basis for the rival group to formulate mobilization strategies. This situation indicates that that actors from the rival group understand the situation, the rules of the game, power relations, and potential opportunities for resistance in the field (Fligstein \& McAdam, 2012). In this context, a petition containing the signature of an anti-redevelopment resident is a crucial resource for the challenger in strengthening their position in the field. Petitions in a social movement that often become an instrument which plays an important role in supporting the struggles of challengers to fight for their interests (Caren et al., 2011; Romanos, 2014).
PERUMNAS to pay for the residents' unit at a price of between IDR 500 million-1 billion (RZ, interview December 2019). This figure is determined based on the land and building tax imposition base (Nilai Jual Objek Pajak-NJOP) and strategic residential location. Thus, both the existence of HGB and knowledge of NJOP have become important resources for the rival groups in their resistance mobilization. Furthermore, residents' resistance to the redevelopment plan has also been made through banners, billboards, and stickers, which are not only a form of symbolic resistance (see Figure 3), but also function to attract sympathy and support from as many people as possible.

However, the rival organization had managed to collect only around 300 votes, 
which is far from the target of 500 votes. This situation happened because the rival organization lack human resources (RB, Interview January 2020). This shortcoming is caused by unclear organizational structure. Indeed, in reality, the group membership is voluntarily. The fluidity of this group in turn becomes an obstacle for the movement. While the petition was being gathered, in December 2019, the rival organization visited the East Jakarta mayor's office to pressure the government to encourage extraordinary meeting of P3SRS. The core argument for the meeting is poor management of the flats by the P3SRS. Through the meeting, the rival organization hopes

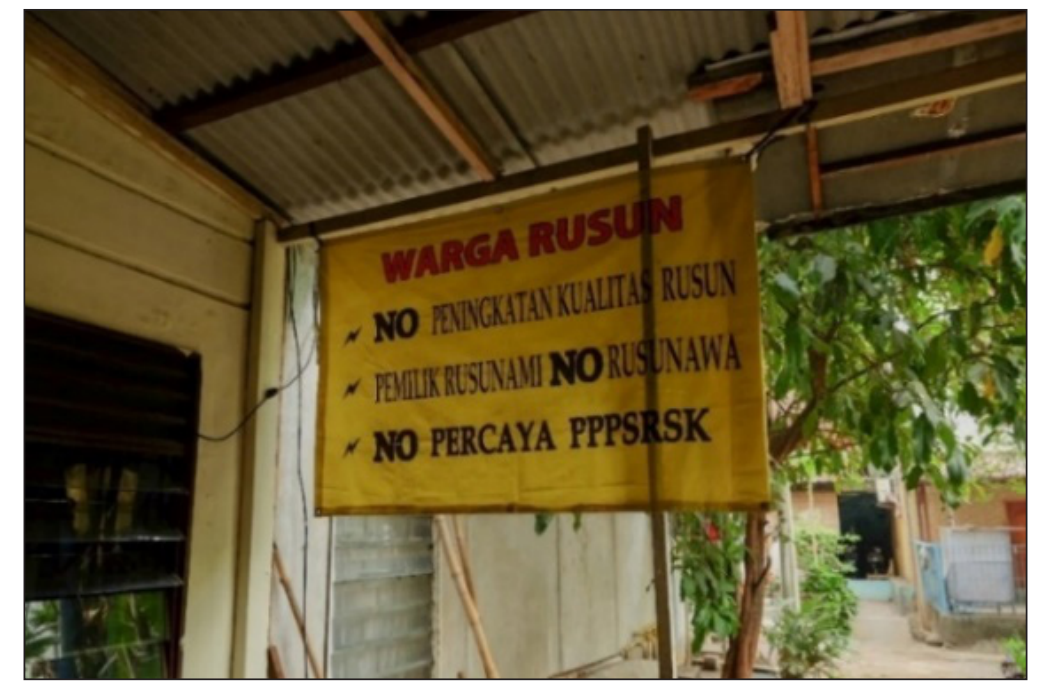

$\mathrm{m}$ a $\mathrm{n}$ a gem ent and to replace the position of chairman of the P3SRS with one of their members.
Figure 3. The symbolic movement of anti-redevelopment group (Source: researcher documentation) of functioning as a neutral mediator, P3SRSK was on the side of the dominant group, thus causing the emergence of a challenger who came from the anti-redevelopment group. Furthermore, considering the influence and authority of P3SRSK in initiating, as well as its potential to thwart the Rumah Susun Klender redevelopment plan, motivates the rival group to control P3SRSK. The rival group mobilized resistance support through community dissatisfaction with P3SRSK's poor management of the flat. The movement was framed to oppose the abuse of authority by P3SRSK and to take over control of the institution a f t e r w a r d. This framing illustrates that the actors in the challenger group are capable to gain the sympathy of other residents, who are antiredevelopment as well, to fight against

Considering the situation, the emergence of the redevelopment plan by PERUMNAS plays an important role as an exogenous shock due to its effect in destabilizing the field. Afterward, the plan triggers pros and cons among residents of the Rumah Susun Klender: the pro-redevelopment group occupies a dominant position considering that the vote acquisition is dominated by them, while a less dominant position is occupied by groups that are resistant to the plan. In addition, a crucial position to observe in this context is the existence of the P3SRS which, using the concept of Fligstein and McAdam (2012), serves as the internal governanceunit in the field. However, instead the dominant group in the field. How actors strategically build cooperation with other actors in the field is a manifestation of what Fligstein \& McAdam (2012) conceptualizes as social skills.

Unfortunately, the rival organization's attempt to impeach the internal management of P3SRSK was not achieved in the meeting. The petition gathered by rival organization has not reached the required number to challenge the votes of the dominant groups. This situation is caused by limited human resources and unclear organizational structure. In addition, the legitimacy of the challenger group is weak because it is not a formal organization. According to Fligstein 
and McAdam (2012), factors such as access to government, understanding of laws and regulations, knowledge of group organizing techniques, all of these can be categorized as resources - or capital (Bourdieu, 2002) for the challenger in contest for positioning in the field. Although crucial, these remain inadequate resources in challenging the power of the dominant group, so long the rival group is not a legal basis (non-formal). Therefore, the lack of legal legitimacy has in turn made the position of the rival group as challenger still relatively fragile in the field.

\section{Conclusion}

In conclusion, the field theory from Fligstein and McAdam (2012) provides an adequate theoretical basis for analyzing the emergence of resistance mobilization in the case of the Rumah Susun Klender redevelopment plan. This study illustrated that the transformation of people resistance into an emergent rival organization as a challenger in the field was not merely caused by the redevelopment plans (exogenous shock). Indeed, it was also caused by a contention (internal dynamics) that occurred between the residents and the P3SRS as the internal governance unit. The residents who are anti-redevelopment was consolidated by, and joined with, the rival organization with the intention of taking over P3SRS' authority in the field to achieve one goal: defeating the redevelopment plan. However, in the end, the mobilization of resistance by challengers was not enough to win the power struggle over governance units in the field.

On the one hand, it cannot be denied that the revitalization plan is a source of exogenous shocks that trigger contention and destabilize the field. However, on the other hand, without the preconditions for internal dynamics between actors in the field, the impetus for the emergence of open mobilization of resistance by challenger groups is unlikely to occur. In addition, this case, at least, provides empirical evidence and affirms Fligstein and McAdam's argument (2012). This theory argues that the struggle for control over internal governance units often occur in the field because it is a valuable resource for both incumbents and challengers. But, as long as governance units remain controlled by the incumbent in the field, changes in the status quo tend to be difficult to be achieved (Fligstein \& McAdam, 2012), as experienced by the rival organization in this case.

\section{Declaration of Ownership}

This article is my original work.

\section{Conflict of Interest}

There is no conflict of interest to declare in this article.

\section{Ethical Clearance}

This study was approved by the institution.

\section{References}

Ancelovici, M. (2021). Conceptualizing the context of collective action: An introduction. Social Movement Studies, 20(2), 125-138. https://doi.org/10.1080/14 742837.2021.1886503

Andri A. (2011). Festival jogokali: Resistensi terhadap penggusuran dan gerakan sosial-kebudayaan masyarakat urban. Jurnal Sosiologi Islam, 1(2), 49-70.

Berg, B. L., \& Lune, H. (2012). Qualitative research methods for the social sciences, 8th Edition. Pearson Education.

Bourdieu, P. (2002). Forms of capital. In N. W. Biggart (Ed.), Reading in Economic sociology (pp. 280-291). Wiley-Blackwell.

Bourdieu, P. (2010). Distinction: A social critique of the judgement of taste (Translated by Richard Nice). Routledge. 
BPS. (2018). Lokasi rumah susun sederhana menurut luas area jumlah blok dan unit di provinsi DKI Jakarta. https://jakarta.bps. go.id/indicator/7/223/1/lokasi-rumahsusun-sederhana-menurut-luas-areajumlah-blok-dan-unit-di-provinsi-dkijakarta.html

Bryman, A. (2012). Social research methods (Fourth Edi). Oxford University Press.

Caren, N., Ghoshal, R. A., \& Ribas, V. (2011). A social movement generation: Cohort and period trends in protest attendance and petition signing. American Sociological Review, 76(1), 125-151. https://doi. org/10.1177/0003122410395369

Chiodelli, F. (2016). International housing policy for the urban poor and the informal city in the global south: A nondiachronic review. Journal of International Development. $\quad$ https://doi.org/10.1002/ jid.3204

Colombijn, F. (2011). Public housing in post-colonial Indonesia: The revolution of rising expectations. Bijdragen Tot de Taal-, Land- En Volkenkunde, 167(4), 437458. $\quad$ https://doi.org/10.1163/2213437990003579

Creswell, J. W. (2014). Research design: Qualitative, quantitative, and mixed methods approaches (fourth edi). SAGE Publications Inc.

Domaradzka, A., \& Wijkström, F. (2019). Urban challengers weaving their networks: between the 'right to housing' and the 'right to the city.' Housing Studies, 34(10), 1612-1634. https://doi.org/10.1080 /02673037.2019.1657561

Flacks, R. (2003). Dynamics of contention: Review. Social Movement Studies, 2(1), 97-98. https://doi. org/10.1080/1474283032000062585

Fligstein, N. (2001). Social skill and the theory of fields. Sociological Theory, 19(2), 105-125.

Fligstein, N., \& McAdam, D. (2011). Toward a general theory of strategic action fields. Sociological Theory, 29(1), 1-26.
Fligstein, N., \& McAdam, D. (2012). A theory of fields. Oxford University Press.

Fringka, Y. (2017). Resistensi berbasis adat: Perlawanan masyarakat nagari III koto, tanah datar, Sumatera Barat, terhadap rencana tambang bukit batubasi. MASYARAKAT: Jurnal Sosiologi, 21(2), 205-231. https://doi.org/10.7454/mjs. v21i2.4670

Hadi, T. M.(2018). Makna lahan dan perlawanan simbolik: Studi tentang konflik agraria pada pembangunan bandara international Yogyakarta. Universitas Indonesia.

Hidayat, R. (2019, May 20). Protes warga di balik rencana perobohan rusunami Klender. Tirto.Id. https://tirto.id/protes-wargadi-balik-rencana-perobohan-rusunamiklender-dRlH

Hidayat, R., \& Sumandoyo, A. (2017, January 9). Dibelit masalah di hunian bertingkat. Tirto.Id. https://tirto.id/dibelit-masalahdi-hunian-bertingkat-cfDS

Hoatson, L., \& Grace, M. (2002). Public housing redevelopment: Opportunity for community regeneration? Urban Policy and Research, 20(4), 429-441. https://doi. org/10.1080/0811114022000032627

Johnson, B., \& Christensen, L. (2014). Educational research: Quantitative, qualitative, and mixed approaches (Fifth Edit). SAGE Publications Inc.

Komalawati, R. A., \& Lim, J. (2020). Reality of compact development in a developing country: Focusing on perceived quality of life in Jakarta, Indonesia. International Journal of Urban Sciences, 1-32. https:// doi.org/10.1080/12265934.2020.1803106

Kriesberg, L., \& Dayton, B. W. (2012). Constructive conflicts: From escalation to resolution (fourth edi). Rowman \& Littlefield Publisher, inc.

Kusno, A. (2012). Housing the margin: Perumahan rakyat and the future urban form of Jakarta. Indonesia, 94 (October), $23-56$. 
Martin, J. L. (2003). What is field theory? American Journal of Sociology, 109(1). https://doi.org/10.1086/375201

McAdam, D., \& Boudet, H. (2012). Putting social movements in their place: Explaining opposition to energy projects in the United States, 2000-2005. Cambridge University Press. https://doi.org/10.1017/ CBO9781139105811

Meyer, D. S. (2012). Protest and political process. In E. Ament, K. Nash, \& A. Scott (Eds.), The Wiley Blackwell Companion to Political Sociology (pp. 397-407). Blackwell Publishing Ltd. https://doi. org/10.4324/9781315634227

Nasution, R. A. (2004). Faktor-faktor yang mempengaruhi penghuni baru untuk memilih tinggal di rumah susun Klender Jakarta Timur. Universitas Diponegoro.

Novenanto, A. (2015). Manusia dan tanah: Kehilangan dan kompensasi dalam kasus lapindo. BHUMI Jurnal Agraria Dan Pertanahan, 1(1), 1-11.

Pasaribu, Z. G. (2013). Makna rumah susun dan keterlekatan komunitas penghuni rumah susun: Studi pada penghuni pemilik dan penghuni pengontrak rw 10 rumah susun Tanah Abang, Jakarta Pusat. Universitas Indonesia.

Rachmawan, D. (2016). Pola eskalasi konflik pembangunan infrastruktur: Studi kasus pembangunan waduk Jatigede Kabupaten Sumedang. MASYARAKAT: Jurnal Sosiologi, 20(2), 193-211. https:// doi.org/10.7454/mjs.v20i2.4618

Romanos, E. (2014). Evictions, petitions and escraches: Contentious housing in austerity Spain. Social Movement Studies, 13(2), 296-302. https://doi.org/10.1080/14 742837.2013.830567

Snow, D. A., Soule, S. A., Kriesi, H., \& McCammon, H. J. (2019). The wiley blackwell companion to social movements (second). Blackwell Publishing Ltd.
Sutanudjaja, E., Manggiasih, B., Pujianto, R., \& Pratiwi, I. (2019). Kampung kota dan representasinya: Perspektif hak atas hunian layak. Rujak Center for Urban Studies.

Swartz, D. L. (2014). Review: Theorizing fields reviewed work(s): A theory of fields by Neil Fligstein and Doug McAdam. Theory and Society (Vol. 43, Issue 6).

Syafruddin, P., \& Adi, I. R. (2017). Relokasi berdampak terhadap kesejahteraan dari sisi kondisi ekonomi warga Kampung Pulo. Jurnal Ilmu Kesejahteraan Sosial, 18(2), 124-138. https://doi.org/10.7454/ jurnalkessos.v18i2.103

Vialita, E., \& Rahmawati, D. (2020). How liveable is living in public housing? A liveability measurement at lowincome apartment of kompleks rumah susun Sombo, Surabaya. IOP Conference Series: Earth and Environmental Science, $452 . \quad$ https://doi.org/10.1088/17551315/452/1/012129

Warouw, F., Kobayashi, H., \& Jung, J. (2010). A study on the open building system for multi-storey housing in Indonesia. Journal of Asian Architecture and Building Engineering, 9(2), 339-346. https://doi. org/10.3130/jaabe.9.339

Widhana, D. H. (2017, January 9). Persoalan rusun dari masa ke masa. Tirto.Id. https:// tirto.id/persoalan-rusun-dari-masa-kemasa-cfDL

Wirutomo, P. (2012). Sosiologi untuk Jakarta: Menuju pembangunan sosial-budaya. Lembaga Pemberdayaan Masyarakat Jakarta.

Wynne, L., \& Rogers, D. (2020). Emplaced displacement and public housing redevelopment: From physical displacement to social, cultural, and economic replacement. Housing Policy Debate, 1-16. https://doi.org/10.1080/105 11482.2020.1772337 